\title{
Involvement of GnRH and Gonadotropin Genes in Oocyte Development of Blue Gourami Females (Trichogaster trichopterus)
}

\author{
Gad Degani1,2 \\ ${ }^{1}$ School of Science and Technology, Tel-Hai Academic College, Tel Hai, Israel \\ ${ }^{2}$ MIGAL_Galilee Technology Center, Kiryat Shmona, Israel \\ Email: gad@migal.org.il
}

Received 21 February 2014; revised 26 March 2014; accepted 3 April 2014

Copyright (C) 2014 by author and Scientific Research Publishing Inc.

This work is licensed under the Creative Commons Attribution International License (CC BY).

http://creativecommons.org/licenses/by/4.0/

(c) (i) Open Access

\begin{abstract}
The goal of this study was to gain a fundamental understanding of RnRH 1 and 3, as well as FSH and LH action, in ovarian follicles during oocyte growth by examining changes in ovarian gene transcription in blue gourami females (Trichogaster trichopterus). The levels of target ovarian mRNAs were determined by quantitative real-time PCR. GnRH1 mRNA levels were higher in oocytes at the previtellogenic stage compared to the vitellogenic and follicular oocytes maturation (FOM) stages. No significant differences in GnRH3 mRNA levels were detected among oocytes during the different stages of development. $\beta \mathrm{LH}$ and $\beta$ FSH mRNA levels were lower in oocytes at the vitellogenic stage compared to the previtellogenic stage. The high transcription of GnRH 1 and 3 in the brain and of FSH and LH in the pituitary of blue gourami as was found in previous studies in our laboratory, compared to mRNA levels changed in ovary during oogenesis, supporting the hypothesis that differences exist between the function of endocrine and autocrine/paracrine of these hormones.
\end{abstract}

Keywords

GnRH and Gonadotropin Genes, Blue Gourami Females

\section{Introduction}

Growth and reproduction in teleosts are tightly regulated, mainly via the hypothalamus-pituitary axis. It is gen-

How to cite this paper: Degani, G. (2014) Involvement of GnRH and Gonadotropin Genes in Oocyte Development of Blue Gourami Females (Trichogaster trichopterus). Advances in Biological Chemistry, 4, 197-202. 
erally accepted that the hypothalamic decapeptide, gonadotropin-releasing hormone (GnRH) controls the release of pituitary gonadotropins (GtHs), follicle-stimulating hormone (FSH) and luteinizing hormone (LH), which in turn control gametogenesis [1]. The sequences of DNA belonging to GnRH from many species have been cloned [2] [3]. Three GnRH genes exist in teleost fish that are comprised of three systems: 1) the midbrain (MB)GnRH system that produces the highly conserved GnRH2, also known as the chicken II GnRH form [4]-[6]; 2) the preoptic (POA)-GnRH system that produces a species-specific GnRH form, GnRH1, which serves as a hypophysiotropic regulator; and 3) the terminal nerve ganglia (TNg)-GnRH system, which produces GnRH3 (also known as salmon GnRH) [5] [6]. It is accepted in many teleost fish orders that the three GnRH genes [3] [5] exist and transcript in the hypothalamus, FSH and LH in the pituitary gland [7], however not much information has been published on autocrine and paracrine secretion of GnRH, FSH and LH from the gonads [8] [9]. GnRH plays an autocrine/paracrine regulatory role in mammalian and fish ovaries. The marine teleost gilthead seabream is an interesting model since during the lifespan of the fish, gonadal tissues develop first as testes, which then regress allowing the development of ovarian follicles [9]. There is evidence of ovarian GnRH playing an autocrine/paracrine regulatory role in controlling ovarian function in vertebrates (fish and mammals). Wong and Zohar [8] suggest that a GnRH gonadotropin axis is present in the gilthead seabream ovary and that FSH and LH, the well-characterized pituitary hormones, may play prominent novel roles in teleost intraovarian communication between oocytes and ovarian follicle cells.

The blue gourami (Trichogaster trichopterus) belongs to the Labyrinthici suborder (characterized by the presence of an air-filled breathing cavity [the labyrinth], located above the gills under the operculum) and the Osphronemidae family. This fish serves as a useful model for studying the role of endocrine regulation on reproduction, since it is multi-spawning and male-dependent, having asynchronic ovary development [10]. Thus, each stage of its gonadal development can be controlled and examined separately in the laboratory [11]-[14]. The profiles of $\beta \mathrm{FSH}, \beta \mathrm{LH}$ and GH secretion and gene expression, as well as the pattern of sex steroid secretion during gonadal development in male and female blue gourami, have been previously reported [15]. The highest levels of blue gourami GH (bgGH) mRNA were found in non-reproductive, active males and in female pituitaries during high vitellogenesis and maturation. These results suggest that GH may play a role in the gonadal cycle and sexual behavior of the blue gourami [16] [17]. The hypothesis examined in the current study is that the autocrine/paracrine of RnRH 1 and 3, as well as FSH and LH and the mRNA of these hormones, change during oogenesis.

\section{Methods}

\subsection{Fish and Sampling}

Trichogaster trichopterus (blue gourami) females and males purchased from local pet shops were separated into different containers and grown for about a month. The fish were grown in aquaria at $27^{\circ} \mathrm{C}$ under a light regime of $12 \mathrm{~h}$ light: $12 \mathrm{~h}$ darkness, fed twice a day with commercial tropical fish food (TetraBits 47.5\% protein, 6.5\% fat) and supplemented once a day with frozen live food (Artemia salina). Males were divided into two groups: 1) mature males (isolated from females); and 2) individual mature males under reproductive conditions that include plants adapted for nest-building. Females were divided into three groups: 1$)$ non-mature females (BW $=1.12 \pm$ $0.37 \mathrm{~g})(\mathrm{n}=10)$ - the ovary of these fish contains mostly oocytes at their previtellogenic stage; 2$)$ mature females that were kept in a group without males $(6.80 \pm 1.14 \mathrm{~g})(\mathrm{n}=10)$; and 3$)$ mature females that were kept with nest-building males for 24 hours $(7.15 \pm 1.10 \mathrm{~g})(\mathrm{n}=6)$. The latter showed oocytes at their final maturation stage.

Fish were sampled and the gonads (small pieces of the ovary) were dissected. The follicles were then accurately isolated using forceps under a microscope to form an enriched sample of the following follicular stages: previtellogenic follicles (from non-mature females), vitellogenic oocytes (from mature grouped females), and follicles at the final oocyte maturation stage (from mature paired females). The samples were kept in RNAsave (Biological industries, Israel) solution until RNA purification.

\subsection{RNA Purification and cDNA Synthesis}

Total RNA was extracted from female follicles $(n=26)$ using Tri-reagent (Invitrogen, CA), according to the manufacturer's recommendations. First-strand cDNA was synthesized by the Verso-Reverse-IT $1^{\text {st }}$ Strand Synthesis Kit (ABgene, UK) from $0.5-2 \mu$ g total RNA, with $1 \mathrm{~h}$ of incubation at $57^{\circ} \mathrm{C}$, followed by 2 min at $94^{\circ} \mathrm{C}$. 


\subsection{Real-Time PCR}

To compare the mRNA levels of GnRH1, GnhRH3, $\beta \mathrm{LH}$ and $\beta \mathrm{FSH}$ in the gonads of the gourami individuals, the relative abundance of their mRNA was normalized with the endogenous reference gene, the $18 \mathrm{~S}$ subunit of rRNA (18S rRNA), using the comparative threshold cycle $\left(\mathrm{C}_{\mathrm{T}}\right)$ method according to [18]. The relative amount of each gene was calculated by the formula $2^{-\Delta \mathrm{C}_{\mathrm{T}}}$, where $\Delta \mathrm{C}_{\mathrm{T}}$ corresponds to the difference between the $\mathrm{C}_{\mathrm{T}}$ measured for each target hormone and that determined for 18S rRNA. To validate this method, serial dilutions were prepared from a gonad (testis and ovary) cDNA sample, and the efficiencies of each target gene and $18 \mathrm{~S}$ rRNA amplifications were compared by plotting $\Delta \mathrm{C}_{\mathrm{T}}$ versus log (template) according to [19]. Linear regressions of the plots showed the following $\mathrm{R}^{2}$ values and efficiencies, respectively: 0.99 and 1 for GnRH1; 0.99 and 0.9 for GnRH3; 0.99 and 0.94 for 18S rRNA; 0.99 and 1 for $\beta \mathrm{LH} ; 0.99$ and 0.87 for $\beta \mathrm{FSH} ; 0.99$ and 1 . Gene-specific primers for real-time PCR were designed using Primer3 Software. Table 1 summarizes the primers used in the real-time PCR. To each of the above PCR mixtures were added $7.5 \mu \mathrm{l}$ of Syber Green Master Mix (ABgene) in a final volume of $15 \mu \mathrm{l}$. Amplification was carried out in a RotorGene 3000 Sequence Detection System (Corbett Research, Sydney, Australia) under the following conditions: for $\mathrm{GnRH} 1$-initial denaturation at $95^{\circ} \mathrm{C}$ for $15 \mathrm{~min}$, followed by 40 cycles of $95^{\circ} \mathrm{C}$ for $10 \mathrm{~s}, 52^{\circ} \mathrm{C}$ for $20 \mathrm{~s}, 72^{\circ} \mathrm{C}$ for $20 \mathrm{~s}$ and $82^{\circ} \mathrm{C} 115 \mathrm{~s}$; for GnRH3initial denaturation at $95^{\circ} \mathrm{C}$ for $15 \mathrm{~min}$, followed by 40 cycles of $95^{\circ} \mathrm{C}$ for $10 \mathrm{~s}, 53^{\circ} \mathrm{C}$ for $20 \mathrm{~s}, 72^{\circ} \mathrm{C}$ for $20 \mathrm{~s}$ and $82^{\circ} \mathrm{C} 10 \mathrm{~s}$; for $\beta \mathrm{LH}$-initial denaturation at $95^{\circ} \mathrm{C}$ for $15 \mathrm{~min}$, followed by 40 cycles of $95^{\circ} \mathrm{C}$ for $10 \mathrm{~s}, 60^{\circ} \mathrm{C}$ for 20 $\mathrm{s}, 72^{\circ} \mathrm{C}$ for $25 \mathrm{~s}$ and $84^{\circ} \mathrm{C} 15 \mathrm{~s}$; for $\beta \mathrm{FSH}$-initial denaturation at $95^{\circ} \mathrm{C}$ for $15 \mathrm{~min}$, followed by 40 cycles of $95^{\circ} \mathrm{C}$ for $10 \mathrm{~s}, 57^{\circ} \mathrm{C}$ for $20 \mathrm{~s}$, and $72^{\circ} \mathrm{C} 20 \mathrm{~s}$; and for $18 \mathrm{~S} \mathrm{rRNA}$ - initial denaturation at $95^{\circ} \mathrm{C}$ for $10 \mathrm{~min}$, followed by 40 cycles of $95^{\circ} \mathrm{C}$ for $20 \mathrm{~s}, 64^{\circ} \mathrm{C}$ for $20 \mathrm{~s}$ and $71^{\circ} \mathrm{C}$ for $20 \mathrm{~s}$. Amplifications of each target gene and the reference gene $18 \mathrm{~S}$ rRNA cDNAs were performed simultaneously in separate tubes in duplicate, and the results were analyzed with the Q-Gene software (BioTechniques Software Library at: www.BioTechniques.com). Dissociation-curve analysis was run after each real-time experiment to ensure that there was only one product. To control for false positives, a non-template negative control was run for each primer pair.

\subsection{Statistical Analysis}

Data are presented as the mean \pm SEM. The significance of the differences between group means of hormone mRNA levels was determined either by one-way analysis of variance (ANOVA), followed by a posteriori Bonferroni post-hoc test or student T-test in males using SPSS 17.0 software. Differences were considered statistically significant at $P<0.05$.

\section{Results}

GnRH1 mRNA levels were higher in oocytes at the previtellogenic stage compared to the vitellogenic and FOM stages (3.5- and 4.1-fold, respectively) (Figure 1 left). No significant differences in GnRH3 mRNA levels were detected among oocytes in the different stages of development (Figure 1 right) ( $\mathrm{P}>0.05$ by ANOVA, Bonferroni post-hoc test). $\beta \mathrm{LH}$ mRNA levels were lower in oocytes at the vitellogenic stage compared to the previtellogenic stage (15.8-fold) ( $\mathrm{P}<0.05$ by ANOVA and Bonferroni post-hoc test) (Figure 2 left). $\beta$ FSH mRNA levels were lower in oocytes at the vitellogenic stage compared to the previtellogenic and FOM stages (25.8- and 7.7-fold, respectively) (Figure 2 right) $(\mathrm{P}<0.05$ by ANOVA and Bonferroni post-hoc test).

\section{Discussion}

It was proposed that gonadotropin-releasing hormone $(\mathrm{GnRH})$ plays an autocrine/paracrine regulatory role in mammalian and fish ovaries [8]. In the current study, the ovary mRNA levels of the expression of GnRH1, GnRH3, follicle-stimulating hormone $(\beta \mathrm{FSH})$ and luteinizing hormone $(\beta \mathrm{LH})$ female gene in oocytes at various stages of oogenesis-previtellogenesis (PV), vitellogenesis (VIT) and final oocyte maturation (FOM) - were described in blue gourami (Trichogaster trichopterus sp.).

The transcription of GnRH 1 and 3 in the brain of blue gourami differs from that found in the ovary during oogenesis. Both GnRH 1 [20] and GnRH 3 [3] had low levels in the brain during PV and high levels in the ovary, as was found in the current study. However, the mRNA level in both the brain and the ovary was higher in FOM compared to VIT [3] [20]. Wong and Zohar (2004) [8] suggest that a GnRH-gonadotropin axis is present in the gilthead seabream ovary, and that FSH and LH, the well-characterized pituitary hormones, may play prominent 
Table 1. Nucleotide sequences of primers for real-time PCR.

\begin{tabular}{|c|c|c|c|}
\hline Gene & Primer name & Sequence 5 '-3, & Reference \\
\hline \multirow{2}{*}{$\beta$ FSH } & GFSHexfor1 & GTTGTCATGGCAGCAGTGTT & \multirow{2}{*}{ Levy et al., 2009} \\
\hline & GFSHexrev1 & CCTCGTGGTAGCAATGTCCT & \\
\hline \multirow{2}{*}{$\beta \mathbf{L H}$} & GLHexfor1 & CCTGACTGTCCTCCTGGTGT & \multirow{2}{*}{ Levy et al., 2009} \\
\hline & GLHexrev1 & TTTGCTTTTGGTTTGCTGTG & \\
\hline \multirow{2}{*}{ GnRH1 } & Expsbfw & TCCAGGAGGAAAGAGGGGTCTGGA & \multirow{2}{*}{ Levy et al., 2009} \\
\hline & Expsbrev & TGCGTCCATTTCCTCTGTCAGTGT & \\
\hline \multirow{2}{*}{ GnRH3 } & sal48fw & TGGAGGCGCGAAGCAGAG & \multirow{2}{*}{ Levy et al., 2009} \\
\hline & sal244rev & CTCTTGGGTTTGGGCACTT & \\
\hline \multirow{2}{*}{$18 S$} & expG18Sf & CCGTCGTAGTTCCGACCATA & \multirow{2}{*}{ Levy et al., 2009} \\
\hline & expG18Sr & CССТTCCGTCAАTTCСТTTA & \\
\hline
\end{tabular}
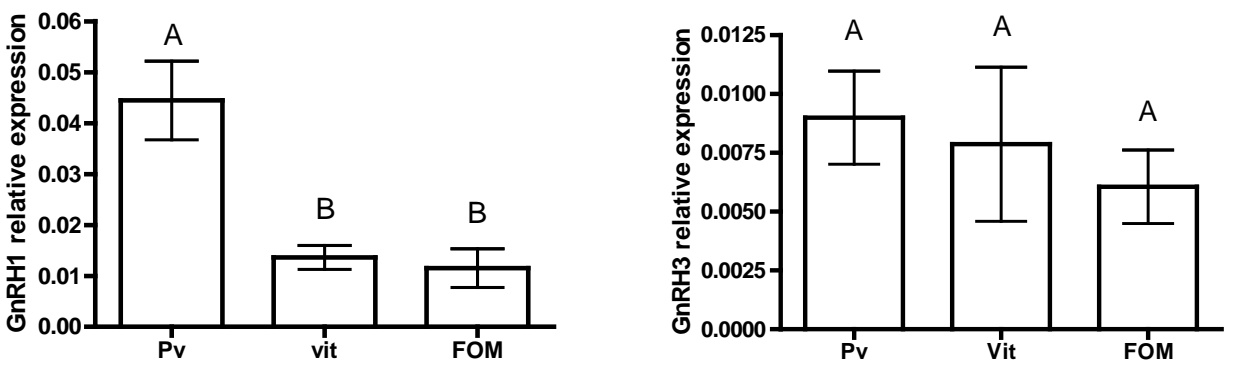

Figure 1. The expression of GnRH1 (left) and GnRH3 (right) genes in oocytes at various stages of oogenesis: previtellogenesis (PV), vitellogenesis (vit) and final oocyte maturation (FOM). Females were kept in groups or with males for one day. Total RNA was extracted and reverse-transcribed to cDNA, which was used as a template for real-time PCR. GnRH1 and GnRH3 mRNA levels were normalized to that of $18 \mathrm{~S}$ rRNA using the $C_{T}$ cycle method, where $2^{-\Delta C_{T}}$ reflects the relative amount of specific gene precursor transcripts. Each histogram represents the average of independent measurements (mean $\pm \mathrm{SEM}$; $\mathrm{n}=6$ - 10). A different letter above the histogram denotes its significant difference from the mRNA levels of the other histograms for GnRH1 (left) ( $P<0.05$ by ANOVA and Bonfferoni post-hoc test) and not significant for GnRH3 (right) (P > 0.05 by ANOVA and Bonfferoni post-hoc test).
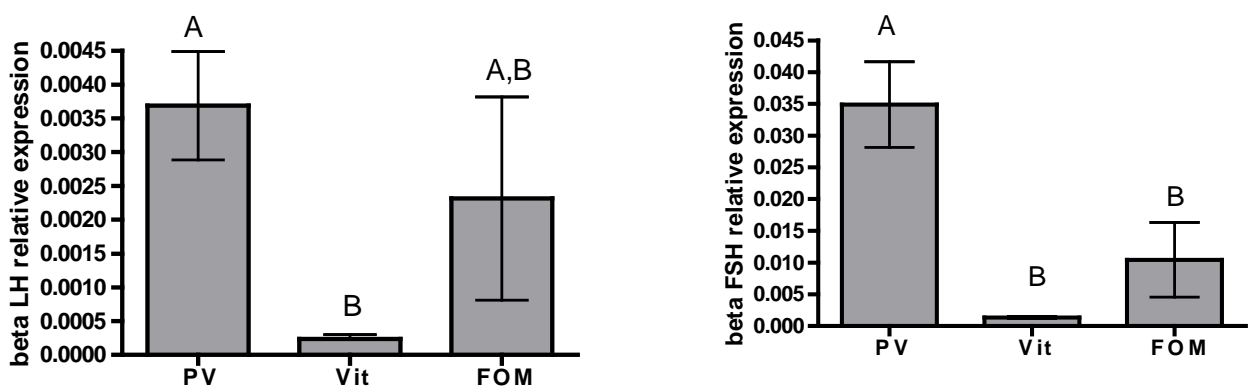

Figure 2. The expression of beta subunit of gonadotropins: $\beta \mathrm{LH}$ (left) and $\beta \mathrm{FSH}$ (right) genes in oocytes at various stages of oogenesis: previtellogenesis (PV), vitellogenesis (vit) and final oocyte maturation (FOM). Females were kept in groups or with males for one day. Total RNA was extracted and reverse-transcribed to cDNA, which was used as a template for real-time PCR. beta subunits of gonadotropin mRNA levels were normalized to that of $18 \mathrm{~S}$ rRNA using the $\mathrm{C}_{\mathrm{T}}$ cycle method, where $2^{-\Delta C_{T}}$ reflects the relative amount of specific gene precursor transcripts. Each histogram represents the average of independent measurements (mean \pm SEM; $n=6-10$ ). A different letter above the histogram denotes its significant difference from the mRNA levels of the other histograms $(\mathrm{P}<0.05$ by ANOVA and Bonfferoni post-hoc test). 
novel roles in teleost intraovarian communication between oocytes and ovarian follicle cells [8]. The novelty of the findings by Wong and Zohar (2004) [8] is that oocytes also expressed these well-characterized gonadotropin subunits, which may serve as autocrine/paracrine factors participating in intraovarian communication. The level of gilthead seabream (Sparus aurata) pituitaries expressed FSH and LH transcripts at much higher levels than ovaries, similar to what was found in blue gourami [14]. The results of the current study support the hypothesis that the autocrine/paracrine of RnRH 1 and 3 may play a function in transferring the oocytes from PV to VIT in blue gourami and might act earlier than in the brain. However, more detailed study is required to support this hypothesis. The highest levels of $\beta \mathrm{FSH}$ and $\beta \mathrm{LH}$ mRNA in the pituitary gland were found in blue gourami females during vitellogenesis and the final stages of oocyte maturation [14].

The level of mRNA of FSH and LH in the pituitary gland remained high in reproductive females during vitellogenesis and the final stages of oocyte maturation. The blue gourami is a multispawner having an asynchronic type of ovary development. The same female can spawn four to five times consecutively with 2- to 3day pauses between spawnings [21]. Therefore, vitellogenic oocytes should be found in the ovary of maturating and post-spawned blue gourami females [22]. A similar pattern of gene expression was found for LH [14]. The levels of its subunit transcript were undetectable in immature females, increased in low vitellogenic fish and showed a sharp increase during high vitellogenesis. The high level of LH transcript remained high at the FOM stage.

In male blue gourami, the mRNA levels of $\operatorname{bg} \beta \mathrm{FSH}$ and $\mathrm{bg} \beta \mathrm{LH}$ in the pituitary were higher than those found in the testis. Thus, Degani and Yomdin are proposing that testis FSH, whose mRNA levels did not change significantly during sexual behavior, does not participate in spermatogenesis, in contrast to LH, which does [23]. The testis mRNA levels of $\mathrm{bg} \beta \mathrm{FSH}$ and $\mathrm{bg} \beta \mathrm{LH}$ were significantly lower than those of the pituitary gland in blue gourami [24].

In summary, the above discussion concludes that the different transcription of GnRH 1 and 3 in the brain and of FSH and LH in the pituitary of blue gourami as was found in previous studies, compared to transcription levels changed in gonads during oogenesis and spermatogenesis described in the present study, supporting the hypothesis that differences exist between the function of endocrine and autocrine/paracrine of these hormones.

\section{References}

[1] Yaron, Z., Gur, G., Melamed, P., Rosenfeld, H., Elizur, A. and Levavi-Sivan, B. (2003) Regulation of Fish Gonadotropins. International Review of Cytology, 225, 131-185. http://dx.doi.org/10.1016/S0074-7696(05)25004-0

[2] Kah, O., Lethimonier, C., Somoza, G., Guilgur, L.G., Vaillant, C. and Lareyre, J.J. (2007) GnRH and GnRH Receptors in Metazoa: A Historical, Comparative, and Evolutive Perspective. General and Comparative Endocrinology, 153, 346-364. http://dx.doi.org/10.1016/j.ygcen.2007.01.030

[3] Levy, G., Gothilf, Y. and Degani, G. (2009) Brain Gonadotropin Releasing Hormone3 Expression Variation during Oogenesis and Sexual Behavior and Its Effect on Pituitary Hormonal Expression in the Blue Gourami. Comparative Biochemistry and Physiology Part A: Molecular \& Integrative Physiology, 154, 241-248. http://dx.doi.org/10.1016/j.cbpa.2009.06.010

[4] Parhar, I.S. (2002) Cell Migration and Evolutionary Significance of GnRH Subtypes. Progress in Brain Research, 141, 3-17. http://dx.doi.org/10.1016/S0079-6123(02)41080-1

[5] Levy, G. and Degani, G. (2012) Involvement of GnRH, PACAP and PRP in the Reproduction of Blue Gourami Females (Trichogaster trichopterus). Journal of Molecular Neuroscience: MN, 48, 603-616. http://dx.doi.org/10.1016/S0079-6123(02)41080-1

[6] Zohar, Y., Munoz-Cueto, J.A., Elizur, A. and Kah, O. (2010) Neuroendocrinology of Reproduction in Teleost Fish. General and Comparative Endocrinology, 165, 438-455. http://dx.doi.org/10.1016/j.ygcen.2009.04.017

[7] Jackson, K., Goldberg, D., Ofir, M., Abraham, M. and Degani, G. (1999) Blue Gourami (Trichogaster trichopterus) Gonadotropic Beta Subunits (I and II) cDNA Sequences and Expression during Oogenesis. Journal of Molecular Endocrinology, 23, 177-187. http://dx.doi.org/10.1677/jme.0.0230177

[8] Wong, T.T. and Zohar, Y. (2004) Novel Expression of Gonadotropin Subunit Genes in Oocytes of the Gilthead Seabream (Sparus aurata). Endocrinology, 145, 5210-5220. http://dx.doi.org/10.1210/en.2004-0558

[9] Soverchia, L., Carotti, M., Andreu-Vieyra, C., Mosconi, G., Cannella, N., Habibi, H., et al. (2007) Role of Gonadotropin-Releasing Hormone (GnRH) in the Regulation of Gonadal Differentiation in the Gilthead Seabream (Sparus aurata). Molecular Reproduction and Development, 74, 57-67. http://dx.doi.org/10.1002/mrd.20484

[10] Degani, G. (2001) Blue Gourami (Trichogaster trichopterus) Model for Labyrinth Fish. Laser Pages Publishing, Jeru- 
salem.

[11] Degani, G. (1993) The Effect of Sexual Behaviour on Oocyte Development and Steroid Changes in Trichogaster trichopterus. Copeia, 4, 1091-1096. http://dx.doi.org/10.2307/1447089

[12] Degani, G. (1993) Reproduction Control in Multi-Spawning Asynchronic Trichogaster trichopterus (Pallas) as a Model for the Anabantidae Family. Threads in Comparative, Biochemistry and Physiology, 1, 1269-1275.

[13] Jackson, K., Degani, G., Bocker, R. and Abraham, M. (1998) Gonadotropin, Growth Hormone Cells and Oocyte Development in Female Gourami after Injection of Gonadotropin-Releasing Hormone Analogue. Journal of Aquaculture in the Tropics, 13, 159-170.

[14] Jackson, K., Goldberg, D., Ofir, M., Abraham, M. and Degani, G. (1999) Blue Gourami (Trichogaster trichopterus) Gonadotropic Beta Subunits (I and II) cDNA Sequences and Expression during Oogenesis. Journal of Molecular Endocrinology, 23, 177-187. http://dx.doi.org/10.1677/jme.0.0230177

[15] Degani, G. and Boker, R. (1992) Sensitivity to Maturation Inducing Steroids and Gonadotropin in the Oocytes of Blue Gourami Trichogaster trichopterus, (Anabantidae, Pallas, 1770). General and Comparative Endocrinology, 85, 430439. http://dx.doi.org/10.1016/0016-6480(92)90088-2

[16] Goldberg, D., Jackson, K., Yom-Din, S. and Degani, G. (2004) Growth Hormone of Trichogaster trichopterus: cDNA Cloning, Sequencing and Analysis of mRNA Expression during Oogenesis. Journal of Aquaculture in the Tropics, 19, 215-229.

[17] Degani, G., Jackson, K., Yom-Din, S. and Goldberg, D. (2006) cDNA Cloning and mRNA Expression of Growth Hormone in Belontiidae (Anabantoidei suborder). The Israeli Journal of Aquaculture, 58, 124-136.

[18] Pfaffl, M.W. (2001) A New Mathematical Model for Relative Quantification in Real-Time RT-PCR. Nucleic Acids Research, 29, e45. http://dx.doi.org/10.1093/nar/29.9.e45

[19] Muller, P.Y., Janovjak, H., Miserez, A.R. and Dobbie, Z. (2002) Processing of Gene Expression Data Generated by Quantitative Real-Time RT-PCR. Biotechniques, 32, 1372-1374, 1376, 1378-1379.

[20] Levy, G. and Degani, G. (2011) Evidence of a Reproduction-Related Function for Pituitary Adenylate Cyclase-Activating Polypeptide-Related Peptide in an Anabantidae Fish. Journal of Molecular Endocrinology, 46, 101-110. http://dx.doi.org/10.1530/JME-10-0065

[21] Degani, G. (1989) The Effect of Temperature, Light, Fish Size and Container Size on Breeding of Trichogaster trichopterus. Israeli Journal of Aquaculture Bamidgeh, 41, 67-73.

[22] Jackson, K., Degani, G. and Goldberg, D. (2004) Transcription of FSH-b, LH-b and Growth Hormone in Female Trichogaster trichopterus (Pallas 1770) Treated with GnRH Analog. IV International Congress on the Biology of Fish, Manaus, 2004, 45-57.

[23] Yomdin, G.D.S. (2011) Hormones Transcription in the Testis of Blue Gourami (Trichogaster trichopterus, Pallas 1770\} During Sexual Behavier te during Sexual Behavior r Trichopterus, Pallas 1770). Bulletin UASVM Animal Science and Biotechnologies, 43-50.

[24] Degani, G., Jackson, K., Goldberg, D., Sarfati, R. and Avtalion, R.R. (2003) $\beta$ FSH, $\beta$ LH and Growth Hormone Gene Expression in Blue Gourami (Trichogaster trichopterus, Pallas 1770) during Spermatogenesis and Male Sexual Behavior. Zoological Science, 20, 737-743. http://dx.doi.org/10.2108/zsj.20.737 